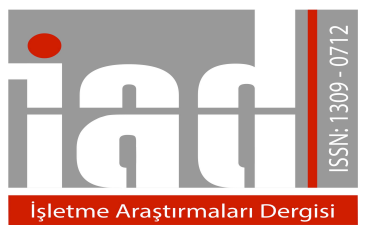

Journal Of

Business Research

Turk

www.isarder.org

\title{
The Effect of Job Satisfaction on Employees' Burnout; A Meta- Analytic Analysis Concerning The Different Occupational Groups
}

\author{
Nazım ÇOĞALTAY \\ Muş Alparslan University \\ Faculty of Education, \\ Department of Educational Sciences Muş/Turkey \\ n.cogaltay@alparslan.edu.tr
}

\begin{abstract}
The purpose of the study is to determine the effect of job satisfaction on employees' burnout. The effect of employees' job satisfaction on their burnout was tested with meta-analysis method which allowed for seeing the results of the independent quantitative research studies between 2005-2016. In total, 48 independent research studies collected and 10177 sample group was obtained. The results of meta analysis via random effects model show that employees' emotional exhaustion and depersonalization is affected by their job satisfaction but employees' reduced personel accomplishment is not affected by their job satisfaction. In this study moderator analysis was performed to see the effect level on different occupational groups.
\end{abstract}

Keywords: Job satisfaction, burnout, meta-analysis

\section{Introduction}

Work, which is as old concept as human history, is an action performed by human being to survive and at the same time it is a fact imposing and comprising a huge part of his or her lifetime. Professional life, which has such a strong effect on the life of individual, is still subject to the researches on several counts nowadays. Conducted researches generally focus on the concepts concerning the organizational outputs such as performance, satisfaction, efficiency and success of the employee in the workplace. The term job satisfaction, which is a mixture of the emotional, cognitive and behavioral features and represents the general attitudes of the employee towards his/her job, is at the head of these concepts ( Shields, 2007; Shraibman, 2008, Willson, 2009). In the most general sense, job satisfaction is an indicator reflecting employee's pleasure or displeasure (Brief, 1998; Diener, 2000; Locke, 1976 ). In other words, it is a composition of the employee's negative and positive feelings with regard to his/her job (Luthans, 1992; Schultz and Schultz, 2005; Verner, 2008). In organizational literature, job satisfaction is a definition regarding how much $\mathrm{s} / \mathrm{he}$ feels happiness while working and it is shaped in accordance with the level of meeting the expectations of the employee (Luthans, 1992; Wray, Luft \& Highland,1996). Vagueness of what can make someone happy or whether the same thing making someone happy is also pleasing for 
anyone else is expressing the difficulty confronted while defining the job satisfaction [(Wray, Luft \& Highland,1996). Within this context, researches conducted about the relation between job satisfaction and many demographic (De Vaus and McAlliter,1991; Schultz and Schultz, 2005; Siu,2002) and organizational variables (Davis, 1988; Kahn, 1973 ) are commonly encountered.

In the most general sense, the term burnout seen as a syndrome, which is shaped as a reaction of the employees against the dense stress and dissatisfaction in working place, is becoming alienated from working of employee (Cherniss, 1980; Maslach, 1976; Fischer, 1983). Burnout, which is a negative feeling experienced in working place, is effected by lots of variables (loyalty, confidence, sense of belonging etc.) supposed to be developed by the employee in organization. Burnout, as such a multidimensional term, has subjected to the researches since 1970s and lots of models have been developed about it (Maslach, 1976; Maslach ve Jackson, 1981; Cherniss, 1980; Pines, Aronson \& Kafry, 1981; Fischer, 1983). The pioneer of these models is a model in which Maslach and his friends discuss the term in three dimensions (Maslach, 1976; Maslach ve Jackson, 1986; Pines and Maslach, 1980). According to this approach, burnout is dealt with in 3 dimensions; $i$ ) Emotional exhaustion; it can be defined as to feel extremely flayed in terms of emotions as an employee. This fraying stands out particularly with fatigue, weakness and debility symptoms. This dimension is depicting the condition of the individual's consuming his or her emotional sources (Wright and Bonett, 1997), ii) Depersonalization; as an employee, embarking on presenting negative attitudes and attitudes unemotionally towards the people who are served by him or her in the line of job (Cordes and Dougherty, 1993), iii) Reduced personal accomplishment; this dimension is related with the employee's feeling her/himself as incompetent, unsuccessful and ineffective on his or her job (Maslach ve Jakson, 1986).

In the literature, it can be seen that the relationship between the employee's burnout and the several variables is tried to be tested (Demerouti, Bakker and Leiter, 2014; Güneş, Bayraktaroğlu and Kutanis, 2014; Montgomery, Todorova, Baban and Panagopoulou, 2013; Polatçı, Ardıç and Türkan, 2014). Employee's job satisfaction perception is one of the most important variables. Although there are lots of independent researches conducted for detecting the relationship between job satisfaction and burnout, there is a need for meta-analysis research in order to understand the strength of the effect between these two variables. Because the results of the researches are variable, this makes it compulsory to assess all the researches as a whole. In this sense, the basic aim of this study is to investigate the effect of the employee's job satisfaction perception on the burnout with a meta-analytic analysis. With the aim of achieving this goal, hypothesis below were tested;

$H_{l}$. The job satisfaction perception of the employees has an effect on the emotional exhaustion in a negative way.

$H_{1 \mathrm{a}}$. The type of the job is a moderator for the effect of job satisfaction on the emotional exhaustion.

$H_{1 \mathrm{~b}}$ The type of the scale used for measuring the effect of the job satisfaction perception of the employees is a moderator for the effect of job satisfaction on the emotional exhaustion.

$H_{2}$. The job satisfaction perception of the employees has an effect the 
depersonalization in a negative way.

$H_{2 \mathrm{a}}$. The type of the job is a moderator for the effect of job satisfaction on depersonalization.

$H_{2 b}$ The type of the scale used for measuring the effect of the job satisfaction perception of the employees is a moderator for the effect of job satisfaction on the depersonalization.

$H_{3}$ The job satisfaction perception of the employees has an effect the feelings on personal achievement in a positive way.

$H_{3 \mathrm{a}}$. The type of the job is a moderator for the effect of job satisfaction on the personal achievement feeling..

$H_{3 \mathrm{~b}}$ The type of the scale used for measuring the effect of the job satisfaction perception of the employees is a moderator for the effect of the job satisfaction on the personal achievement feeling.

\section{Method}

\subsection{Research Pattern}

In this study, the effect of the employees' perception on the burnout was tested by meta-analysis method which provides the opportunity of seeing all the thing as a whole by combining lots of independent quantitative research results (Lipsey ve Wilson, 2001).

\subsection{Review Strategy and Criteria for Including/Excluding}

In order to specify the researches that will be included in the meta-analysis, firstly literature review was conducted in the databases YOK and ULAKBIM in which the researches of Turkey are stored. Additionally, literature review was performed in Google Academic and EBSCO databases. The deadline for the researches including in the study was 10 January, 2016. Specified criteria for inclusion are stated below;

- $\quad$ The studies were conducted between 2005 and 2016.

- The studies include statistical information required for correlational metaanalysis ( $\mathrm{n}$ and $\mathrm{r}$ scores).

- The general score of the job satisfaction scale was to be calculated.

- Sample group was to be within the borders of Turkey.

- For articles, to be published in the refereed journal.

In order to access to the job satisfaction and burnout studies conducted in Turkey, literature review was conducted in the search engines of the databases by using burnout, job satisfaction, job content, depersonalization, emotional exhaustion, reduced personal accomplishment terms. According to the results of the enquiries conducted in the light of the criteria shaped by the study, it was understood that there were 48 independent studies which include the data allowing the meta-analysis. Descriptive statistics regarding the researches included in the meta-analysis were presented in Table1. 
Table 1. Features of the studies included in the meta-analysis

\begin{tabular}{|c|c|c|c|c|c|c|c|c|c|}
\hline \multicolumn{2}{|c|}{ Characteristic } & 1 & 2 & 3 & 4 & 5 & 6 & 7 & Total \\
\hline \multicolumn{2}{|c|}{ Publication } & 2016 & 2015 & 2014 & $\underline{2013}$ & 2012 & 2011 & 2010 & - \\
\hline Years of & $N$ & $\overline{-}$ & $\overline{4}$ & 5 & 10 & 1 & 8 & 6 & \\
\hline \multirow[t]{4}{*}{ Research } & $\%$ & - & 8,4 & 10,5 & 20,8 & 2,1 & 16,8 & 12,6 & \\
\hline & & 2009 & 2008 & 2007 & $\underline{2006}$ & 2005 & & & \\
\hline & $N$ & 5 & 2 & 4 & 2 & 1 & & & 48 \\
\hline & $\%$ & 10,5 & 4,2 & 8,4 & 4,2 & 2,2 & & & 100 \\
\hline \multirow{3}{*}{$\begin{array}{l}\text { Type of } \\
\text { Research }\end{array}$} & & $\begin{array}{l}\text { Master } \\
\text { Theisis }\end{array}$ & $\begin{array}{c}\text { Doctoral } \\
\text { Thesis }\end{array}$ & Article & & & & & \\
\hline & $N$ & 39 & - & 9 & & & & & 48 \\
\hline & $\%$ & 81,2 & - & 18,8 & & & & & 100 \\
\hline \multirow{3}{*}{$\begin{array}{l}\text { Sample } \\
\text { Area }\end{array}$} & & Marmara & Aegean & $\begin{array}{c}\text { Meditearr } \\
\text { enan }\end{array}$ & $\begin{array}{c}\text { Black } \\
\text { Sea }\end{array}$ & $\begin{array}{c}\text { E. } \\
\text { Anatolia }\end{array}$ & $\begin{array}{c}\text { C. } \\
\text { Anatolia }\end{array}$ & $\begin{array}{l}\text { Across } \\
\text { Turkey }\end{array}$ & \\
\hline & $N$ & 12 & 8 & 7 & 2 & 3 & 5 & 11 & 48 \\
\hline & $\%$ & 24,7 & 16,8 & 14,7 & 4,2 & 6,3 & 10,5 & 22,6 & 100 \\
\hline
\end{tabular}

\subsection{Data Analysis}

The effect magnitude obtained from the meta-analysis is not a standard scale used for identifying the strength and the direction of the relationship in the study (Borenstein, Hedges, Higgins ve Rothstein, 2009). As the effect size, Pearson correlation coefficient ( $r$ ) was calculated in this study. This effect size is used for calculating the direction and the quantity of the relationship between two independent variables. In meta-analysis model, there are two basic models; $i$ ) fixed effect model and ii) random effects model. While deciding which model to use, which model's prerequisites are provided by features of the researches included in the study is taken into account (Borenstein, Hedges, Higgins ve Rothstein, 2009; Hedges ve Olkin, 1985; Littel, Corcoran and Pillai, 2008). While fixed effect model estimates a single effect commonly expressed for every study, random effects model estimates the average of the effect's distribution in the researches .( Borenstein, Hedges, Higgins ve Rothstein, 2009; Hedges and Olkin, 1985). Considering the aforementioned features as a whole, it was decided that using the random effect model is more appropriate for this study. Furthermore, regarding the publication bias, Funnelplot method was utilized. Funnel plots belonging to the researches included in the meta-analysis were presented in the research appendix (appendix 4). In the figures, there was no prove observed for the existence of any effect connected to the publication bias in the researches included in the meta-analysis (Littel, Corcoran and Pillai, 2008; Shadish, Hedges and Pustejovsky, 2014). For the data analysis, Comprehensive Meta-Analysis Program and Microsoft Excel were utilized.

\section{Results}

The meta-analysis results demonstrating the effect of the job satisfaction on the level of employees' emotional exhaustion were presented in Table 2. Findings totally supported the Hypothesis $\mathrm{H}_{1}$ suggesting job satisfaction effects the employee's emotional exhaustion. According to the random effects model, the level of effect (r) between the employee's emotional exhaustion and level of the job satisfaction was calculated as -48 . When this value was assessed in terms of the effect classification. (Cohen, 1988; Thalheimer ve Cook, 2002, it showed that employees' job satisfaction perception effects their emotional exhaustion negatively and large. This finding is important because it shows that the increase of the job satisfaction perception will 
decrease emotional exhaustion considerably.

Findings didn't support the hypothesis $\mathrm{H}_{1 \mathrm{a}}$ stating the different job of the employees have a moderator role between the level of job satisfaction and emotional exhaustion. Regarding the job type variable, effect difference $\left(\mathrm{Q}_{b}=8,73, p>.05\right)$ was found statistically insignificant. This finding showed that the performed job didn't create any difference on the negative relation between job satisfaction level and exhaustion of all the employees. Because moderator analysis can be seen as a sub-group analysis, the effect levels of the occupational groups included in the study can be observed from Table 3 one by one. According to that, this effect level is -41 for the teachers, -40 for the academicians, -47 for call centre employees, -71 for bankers, -43 for doctors, -56 for referees, -50 for hospital employees, -48 for airport employees, -49 for nurses, -48 for eventide home employees, -48 for blue-collars. For all occupational groups, these effects' level is negative and large.

As it can be seen from the Table 2, findings didn't support the hypothesis $H_{1 b}$ stating that different job satisfaction scales used in the researches play a moderator role on the effect of employees' job satisfaction levels on their emotional exhaustion. Regarding used scale variable, the effect difference $\left(\mathrm{Q}_{b}=4,41, p>.05\right)$ was found statistically insignificant. This finding showed that different job satisfaction scales used in the researches included in the study resulted similarly and they didn't create any statistical difference. This signifies that aforesaid scales are working harmoniously.

Table 2. The effect of job satisfaction on emotional exhaustion: The results of meta-analysis

\begin{tabular}{|c|c|c|c|c|c|c|c|}
\hline \multirow[b]{2}{*}{ Variable } & \multirow[b]{2}{*}{$\mathbf{k}$} & \multirow[b]{2}{*}{$\mathbf{N}$} & \multirow[b]{2}{*}{$r$} & \multicolumn{2}{|c|}{ CI } & \multirow[b]{2}{*}{$Q$} & \multirow[b]{2}{*}{$Q_{b}$} \\
\hline & & & & $\begin{array}{c}\text { Lower } \\
\text { Limit }\end{array}$ & $\begin{array}{l}\text { Upper } \\
\text { Limit }\end{array}$ & & \\
\hline Emotional exhaustior & 48 & 10177 & $-.48^{*}$ & -.53 & -.43 & $499,78^{*}$ & \\
\hline Moderator [Profession] & & & & & & & 8,73 \\
\hline Teachers & 10 & 2482 &,$- 41 *$ &,- 51 &,- 29 & & \\
\hline Academicians & 2 & 340 &,$- 40 *$ &,- 61 &,- 13 & & \\
\hline Call Centre Employees & 2 & 289 &,$- 47 *$ &,- 67 &,- 22 & & \\
\hline Bankers & 2 & 339 &,$- 71^{*}$ &,- 83 &,- 54 & & \\
\hline Doctors & 4 & 505 &,$- 43 *$ &,- 58 &,- 24 & & \\
\hline Referees & 2 & 324 &,$- 56^{*}$ &,- 73 &,- 34 & & \\
\hline Hospital Employees & 4 & 841 &,$- 50 *$ &,- 64 &,- 33 & & \\
\hline Airport Employees & 2 & 321 &,$- 48 *$ &,- 67 &,- 24 & & \\
\hline Nurses & 5 & 781 &,$- 49 *$ &,- 62 &,- 33 & & \\
\hline Eventide Home & & 203 & & & & & \\
\hline Employees & 2 & &,$- 48 *$ &,- 68 &,- 20 & & \\
\hline Blue-Collars & 3 & 568 &,$- 48 *$ &,- 64 &,- 28 & & \\
\hline Others & 10 & 3184 &,$- 50 *$ &,- 59 &,- 40 & & \\
\hline \multicolumn{2}{|c|}{ Moderator [Job satisfaction scales] } & & & & & & 4,41 \\
\hline Minnesota & 27 & 5678 &,$- 51 *$ &,- 57 &,- 45 & & \\
\hline Hackman ve Oldman & 10 & 2053 &,$- 40 *$ &,- 50 &,- 29 & & \\
\hline Paul Spector & 3 & 552 &,$- 55^{*}$ &,- 69 &,- 38 & & \\
\hline Others & 8 & 1894 &,$- 43 *$ &,- 54 &,- 29 & & \\
\hline
\end{tabular}

$* p<.01$ 
At the Table 3, meta-analysis results showing the effect strength of the employees' job satisfaction perception on depersonalization were presented. Findings supported hypothesis $\mathrm{H}_{2}$ suggesting that job satisfaction effects depersonalization of the employees. According to the random effects model, the effect level (r) between employees' depersonalization and job satisfaction level in Turkey sample was calculated as -29 . This value showed that employees' job satisfaction perception for their jobs effects their depersonalization in a negative way and with medium level. The results of the analysis can be read as if employees' job satisfaction perceptions increase, their depersonalization will decrease.

Findings supported Hypothesis $\mathrm{H}_{2 \mathrm{a}}$ stating that different jobs performed by the employees have a moderator role between their job satisfaction and depersonalization. Considering the job type variable in the conducted moderator analysis, effect difference $\left(\mathrm{Q}_{\mathrm{b}}=22,17, \mathrm{p}<.05\right)$ was found significant. This result showed that the effect of the employee's job satisfaction level on their depersonalization differentiates according to the kind of the job performed by the employee. According to this result, this effect level is -, 14 for the teachers,,- 34 for the academicians,,- 40 for call centre employees,,- 37 for bankers, -,37 for doctors, -,03 for referees, ,35 for hospital employees, -,38 for airport employees, -,32 for nurses, -,35 for eventide home employees, -,35 for blue-collars. For all occupational groups, this aforesaid effect level is negative oriented and in broad level. When it is scrutinized in terms of effect levels, the effect of the job satisfaction on the depersonalization is low and insignificant for the teachers and referees, it is broad for call centre employees, it is moderate and statistically significant for all of the other occupational groups. This finding demonstrated that the effect of the job satisfaction on the depersonalization differentiates for the different occupational groups.

As it can be seen from the Table 3, the results obtained from the analysis didn't support the hypothesis $\mathrm{H}_{2 b}$ arguing that different job satisfaction scales used in the studies plays a moderator role between the employees' job satisfaction level and their depersonalization. When the used scale variable was concerned, effect difference $\left(\mathrm{Q}_{\mathrm{b}}=\right.$ $4,47, p>.05)$ was found statistically insignificant. This result showed that different job satisfaction scales used in the studies included in meta-analysis produce similar results and they don't cause any statistical difference. 
Table 3. The effect of job satisfaction on depersonalization: The results of metaanalysis

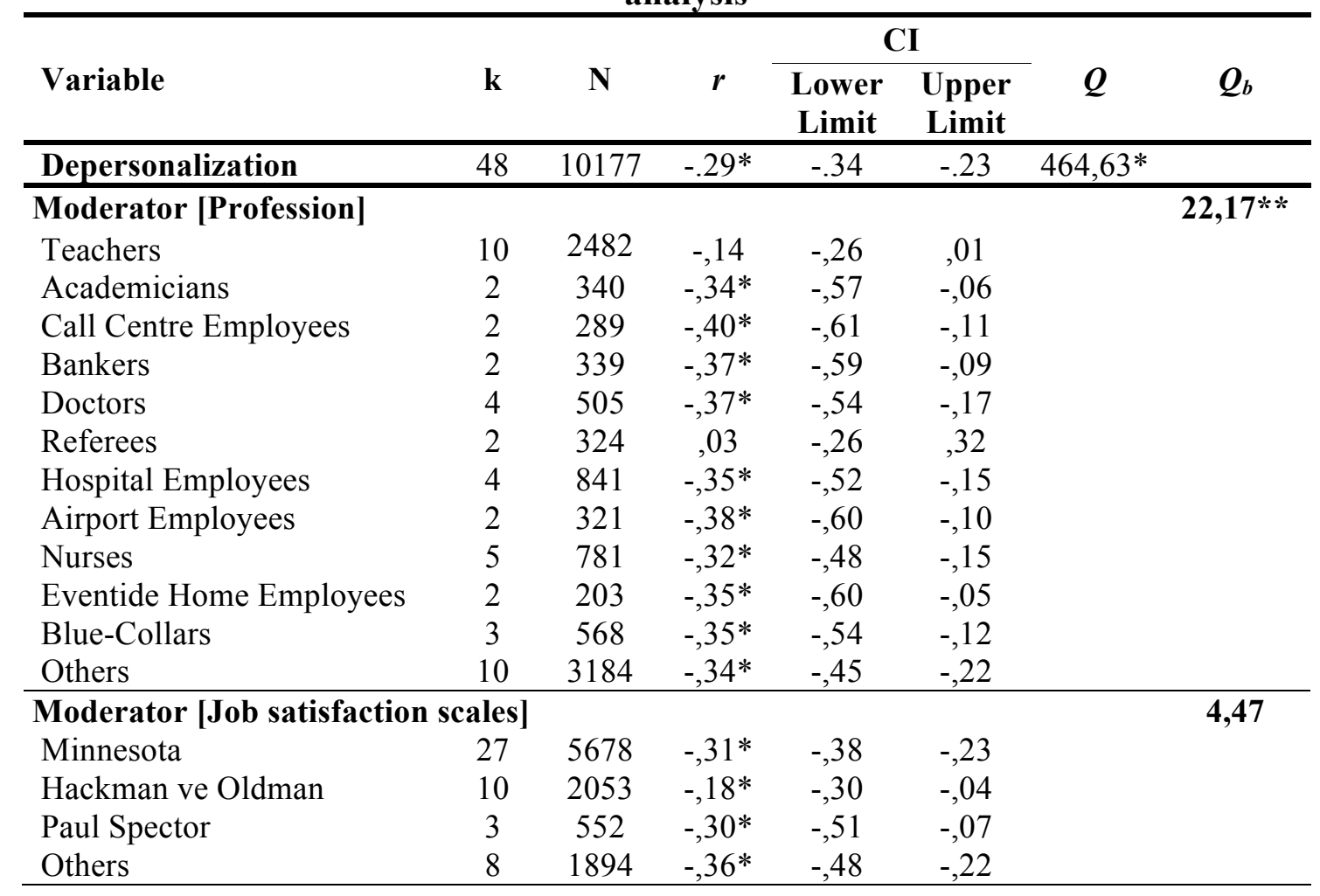

$* p<.01 \quad * * p<.05$

Meta-analysis results indicating effect strength of the employee's job satisfaction perceptions on their personal achievement feeling were presented at the Table 4. The findings didn't support the hypothesis $\mathrm{H}_{3}$ suggesting that employees' job satisfaction effect their personal achievement feeling. In respect of random effect model, in the Turkey sample, effect level (r) between the employees' job satisfaction levels and decrease of their personal achievement feeling was calculated as -07 . This value demonstrated that employees' job satisfaction perceptions for their work has a low level effect on their personal achievement feeling. From this result forth, it was understood that there is a statistically insignificant relation between job satisfaction and the decrease of personal achievement feeling.

Findings supported the hypothesis $\mathrm{H}_{3 \mathrm{a}}$ stating that different works performed by the employees play a moderator role between their job satisfaction and personal achievement feeling. In the moderator analysis conducted, when work type was regarded, effect difference $\left(\mathrm{Q}_{\mathrm{b}}=71,17, \mathrm{p}<.01\right)$ was found statistically insignificant. This finding showed that the low level relationship between job satisfaction level of the employees and their personal achievement feeling differentiates according to the occupation which they perform. When it is assessed in the basis of occupational groups, this effect level is ,01 for the teachers,,- 15 for the academicians,,- 25 for call centre employees, , 12 for bankers, 35 for doctors, -, 14 for referees, , 23 for hospital employees, ,22 for airport employees, ,26 for nurses, ,39 for eventide home employees, ,06 for bluecollars workers. When it is assessed in terms of effect levels, the effect of the job satisfaction on the depersonalization is low and statistically insignificant for teachers, academicians, bankers, referees and blue collar workers. This effect is at the mid-level 
and negative oriented for the call centre employees. For the hospital employees, airport employees and nurses, it is mid-level and positive oriented. For the eventide home employees, this effect is large and positive. These findings are important in terms of showing that the effect of the job satisfaction on the personal achievement feeling has different effect on the different occupational groups. As it can be seen at the Table 4, the findings obtained from the analysis didn't support the hypothesis $\mathrm{H}_{3 \mathrm{~b}}$ stating that different job satisfaction scales used in the researches play a moderator role between employees' job satisfaction levels and depersonalization. When the used scale variable was considered, effect difference $\left(\mathrm{Q}_{\mathrm{b}}=3,27, \mathrm{p}>.05\right)$ was found statistically insignificant. This finding presented that different job satisfaction scales used in the researches included in the meta-analysis shows the similar results and they don't cause any difference in statistical sense.

Table 4. The effect of job satisfaction on reduced personal achievement: The results of meta-analysis

\begin{tabular}{|c|c|c|c|c|c|c|c|}
\hline \multirow{2}{*}{ Variable } & \multirow{2}{*}{$\mathbf{k}$} & \multirow{2}{*}{$\mathbf{N}$} & \multirow{2}{*}{$r$} & \multicolumn{2}{|c|}{$\begin{array}{l}\text { Confidence } \\
\text { Interval }\end{array}$} & \multirow{2}{*}{$Q$} & \multirow{2}{*}{$Q_{b}$} \\
\hline & & & & $\begin{array}{l}\text { Lower } \\
\text { Limit }\end{array}$ & $\begin{array}{l}\text { Upper } \\
\text { Limit }\end{array}$ & & \\
\hline $\begin{array}{l}\text { Reduced Personal } \\
\text { Achievement } \\
\end{array}$ & 48 & 10177 & .07 & -.03 &, 17 & $1220,86^{*}$ & \\
\hline Moderator [Profession] & & & & & & & $71,17 *$ \\
\hline Teachers & 10 & 2482 &, 01 &,- 19 & ,20 & & \\
\hline Academicians & 2 & 340 &,- 15 &,- 55 &, 30 & & \\
\hline Call Centre Employees & 2 & 289 &,- 25 &,- 62 & 21 & & \\
\hline Bankers & 2 & 339 &,- 12 &,- 53 & 33 & & \\
\hline Doctors & 4 & 505 &, $35^{*}$ &, 03 & 60 & & \\
\hline Referees & 2 & 324 &, 14 &,- 31 &, 54 & & \\
\hline Hospital Employees & 4 & 841 & ,23 &,- 10 &, 51 & & \\
\hline Airport Employees & 2 & 321 & ,22 &,- 24 & 60 & & \\
\hline Nurses & 5 & 781 &, 26 &,- 01 &, 51 & & \\
\hline Eventide Home Employee & 2 & 203 &, $39 *$ &,- 07 & ,71 & & \\
\hline Blue-Collars & 3 & 568 &, 06 &,- 31 & ,41 & & \\
\hline Others & 10 & 3184 &,- 10 &,- 29 &, 11 & & \\
\hline \multicolumn{6}{|c|}{ Moderator [Job satisfaction scales] } & & 3,27 \\
\hline Minnesota & 27 & 5678 &, 01 &,- 14 &, 13 & & \\
\hline Hackman ve Oldman & 10 & 2053 &, 16 &,- 06 &, 37 & & \\
\hline Paul Spector & 3 & 552 &, 04 &,- 36 & ,43 & & \\
\hline Others & 8 & 1894 & ,22 &,- 02 &, 44 & & \\
\hline
\end{tabular}

$* p<.01$

\section{Discussion And Suggestions}

Meta-analysis findings obtained from the studies reached within the scope of the study showed that employees' job satisfaction level has a large and negative oriented effect on their emotional exhaustion. This finding is important in terms of showing that increase of the employees' job satisfaction makes emotional exhaustion decreased when mode of scoring of the scales by which these aforesaid terms were measured is regarded. High job satisfaction which means having a positive attitude towards the job or loving the job (Locke, 1976; Luthans, 1992; Wray, Luft \& Highland, 1996) can reduce the appearance possibility of some symptoms such as fatigue, weakness and 
lassitude in the workplace by decreasing the employee's emotional exhaustion. Being supported by meta-analysis which is a higher level method, this relationship executed by personal studies (Becker, Milad \& Klock, 2006; Sarros \& Sarros, 1987; Scanlan \& Still, 2013 reveals the importance of the actions. Since high level job satisfaction means employee's healthy occupational life in terms of physic and soul. Additionally, this meta-analysis study is important in terms of revealing whether this effect of job satisfaction on the emotional exhaustion changes according to the profession or not. The findings obtained from the moderator analysis showed that the different effect levels of the occupational groups included in the study are statistically insignificant. It was seen that job satisfaction has a negative effect on the emotional exhaustion for all the occupational groups. With all that, it was seen that different job satisfaction scales used in the independent researches gave the same results and didn't cause any difference in statistical sense. This is also important in terms of showing that aforesaid different job satisfaction scales measure the similar quality.

Findings are showing that depersonalization, which is a different dimension of exhaustion and means doing what is necessary for one's job emotionlessly (Cordes and Dougherty, 1993; Pines and Maslach, 1980) is also effected by the job satisfaction. The meta-analysis result showed that job satisfaction has a negative oriented and mid-level effect on the employees' depersonalization. This result also showed that the negative attitudes, which appear with the symptoms such as humiliating, underestimating or behaving in a rude way towards the people to whom they serve in the workplace, are effected by the job satisfaction. It showed that as the job satisfaction increases, the negative attitudes could decrease remarkably. However, it is understood that the job kind has a moderator role on the aforesaid effect. The findings of the moderator analysis remarked that the negative effect of the job satisfaction on the depersonalization of the employees differentiates according to the performed job. It was understood that for all the occupations except from teachers and referees the effect of the job satisfaction on the depersonalization is statistically significant. It was assessed as this condition could be rooted from the nature of the occupations. As an example, when it is considered that the teachers' approaching to their students in a emotionless way may create much more negative results for the sake of their occupation, teachers may not present attitudes in the context of depersonalization whether their job satisfaction decreases or increases. This argument should be supported by qualitative researches. Furthermore, it was understood that this job satisfaction scale which is also used by the exhaustion dimension gives the similar results and is not a moderator.

Results showed that job satisfaction has a statistically insignificant effect in terms of the reduced personal achievement sub-dimension. By contrast with other dimensions, employees' job satisfaction perceptions didn't reveal a statistically significant effect on their personal achievement feelings. It was assessed that scoring mode of substances which forms the third dimension of Mashlach exhaustion inventory might have a role in this finding. In contrast with others, the items forming this dimension need to be scored conversely. This condition was not regarded for some researches included in the metaanalysis and this might cause this effect level to be found statistically insignificant. Correlation values reported by the researches participated in the meta-analysis are positive in some studies and negative in the others. What is expected is that aforesaid relation is positive oriented. When the researches which are positive in some studies and negative in others were combined with meta-analysis, they neutralized each other. 
However it was assessed that this scoring type was overlooked in the researches; their accuracy was admitted because of the fact that research reports was subject to the scientific referee process. Furthermore, reported correlation values were directly included in the analysis in accordance with the scientific ethic rules. Moderator analysis findings showed that job type causes statistically significant difference in that effect level. Moderator analysis findings demonstrated that job satisfaction has a positive and mid-level effect on the personal achievement feeling for the doctors and eventide home employees. According to this finding, when the doctors and eventide home employees' job satisfaction increases, their personal achievement feeling increases, as well. In terms of this dimension, it was also seen that the used job satisfaction scale doesn't cause any statistically significant differentiation. Through the findings obtained as a result of the analyses, suggestions can be listed as follows;

* It was seen that in some of the researches reached in the extent of this study, (r) value and sample number of the groups were not reported. In that sense, the researchers should report the findings providing an opportunity for metaanalysis in their studies. Therefore, their studies will not be only one research finding.

* If the researches are using Maslasch's burnout inventory, they should be more careful in scoring the items related with the personal achievement feeling decrease dimension which is the third dimension of the aforesaid inventory. Especially in the rational and correlational analysis with the other independent variables, to scoring this dimension has a great importance.

* Similar meta-analysis researches should be done in order to specify the other predictors of burnout.

Quality studies should be done in order to understand the defining and predictor effect of the employees' job satisfaction perception.

* Against the burnout symptoms which may appear in work place, the headmasters or the employers should take precautions to increase the job satisfaction of the employees. 


\section{References}

Note: References marked with an asterisk indicate studies included in the metaanalysis

*Arasan, B. N. A. (2010). Akademsiyenlerde yaşam doıyumu, iş doyumu ve mesleki tükenmişlik düzeylerinin belirlenmesine yönelik bir araştırma (Yayımlanmamış yüksek lisans tezi). Uşak Üniversitesi, Uşak.

*Akgüç, O. M. (2011). Özel güvenlik görevlilerinin iş doyumu ve motivasyonlarlyla tükenmişlik düzeyleri arasındaki ilişkinin incelenmesi (Yayımlanmamış yüksek lisans tezi). Maltepe Üniversitesi, İstanbul.

*Aktaş, H., \& Şimşek, E. (2015). Bireylerin örgütsel sessizlik tutumlarında iş doyumu ve duygusal tükenmişlik algılarının rolü. Uluslararası Yönetim Ikktisat ve İşletme Dergisi,11 (24), 205-230.

*Arslan, R., \& Acar, B.N. (2013). Yaşam doyumu, iş doyumu ve mesleki tükenmişlik kavramlarına yönelik akademisyenler üzerinde bir araştırma. Süleyman Demirel Üniversitesi Iktisadi ve İdari Bilimler Fakültesi Dergisi, 18(3), 281-298.

*Atila, E. (2014). The relatıonship between burnout and job satısfactıon levels of english teachers and instructors: Ankara case (Yayımlanmamış yüksek lisans tezi). Çanakkale Onsekiz Mart Üniversitesi, Çanakkale.

*Atlandı, D. (2010). Çă̆rı merkezi çalışanlarında tükenmişlik ve iş doyumu düzeylerinin incelenmesi (Yayımlanmamış yüksek lisans tezi). Haliç Üniversitesi, İstanbul.

*Avcı, S. (2013). Farklı mesleklerde çalışan kadınların yaşam doyumu, iş doyumu, tükenmişlik ve algllanan cinsiyet ayrımcılığ düzeylerinin depresyon ile ilişkisinin incelenmesi (Yayımlanmamış yüksek lisans tezi). Maltepe Üniversitesi, İstanbul.

*Avşaroğlu, S., Deniz, M.E., \& Kahraman, A. (2005). Teknik öğretmenlerde yaşam doyumu iş doyumu ve mesleki tükenmişlik düzeylerinin incelenmesi. Selçuk Üniversitesi Sosyal Bilimler Enstitüsü Dergisi, 14, 115-129.

*Bayrak, M. (2014). Illkokullarda ĕgitim veren sınıf öğretmenlerinin mesleki doyum ve tükenmişlik düzeyi (Yayımlanmamış yüksek lisans tezi). Gaziantep Üniversitesi, Gaziantep.

Becker, J.L, Milad, M.P., \& Klock, S.C. (2006). Burnout, depresssion and career satisfaction: cross-sectional study of obstetrics and gynecology residents. American Journal Obstetrics \& Gynecologic Oncology 195 (5), 1444-1449.

*Berber, S. (2011). Tükenmişlik ve iş tatmini arasındaki ilişki: kule personeli üzerinde bir araştırma (Yayımlanmamış yüksek lisans tezi). Gazi Üniversitesi, Ankara.

*Bilgin, Y. Ş. (2007). Huzurevi çalışanlarının iş doyumu ve tükenmişlik düzeylerinin araştırılması (Yayımlanmamış yüksek lisans tezi). Ankara Üniversitesi, Ankara.

Brief, A. P. (1998), Attitudes in and Around Organizations, Thousand Oaks, CA: Sage.

Borenstein, M., Hedges, L. V., Higgins, J. P. T.,\& Rothstein, H. R. (2009).Introduction to meta-analysis.UK: Wiley.

*Ceran, S. Ö. (2010). İsgörence algllanan sosyal destek ile mesleki tükenmişlik ve iş 
doyumu ilişkisinin incelenmesi (Yayımlanmamış yüksek lisans tezi). Maltepe Üniversitesi, İstanbul.

*Cöbek, S. (2010). Tersane çalışanlarının mesleki tükenmişlik seviyelerinin iş tatmini üzerindeki etkisi: Kdz.Ereğli bölgesi örneği (Yayımlanmamış yüksek lisans tezi). Zonguldak Karaelmas Üniversitesi, Zonguldak.

Cherniss, C. (1980). Professional burnout in human service organizations. New York: Praeger Press.

Cordes, C. L., \& Dougherty, T. W. (1993). A review and integration of research on job burnout. Academy of Management Review, 18 (4), 621-656

Cohen, J. (1988). Statistical power analysis for the behavioral sciences. Hillside, NJ: Lawrence Erlbaum Associates.

Davis, K. (1988), İşletmede İnsan Davranışı-Örgütsel Davranış, Çev, Kemal Tosun, İstanbul Üniversitesi İşletme Fakültesi Yayını, İstanbul.

*Demirkol, İ. (2006). Avukatlarda iş doyumu, tükenmişlik ve denetim odağının bazı demografik değişkenler bağlamında incelenmesi (Yayımlanmamış yüksek lisans tezi). Mersin Üniversitesi, Mersin.

Demerouti, E., Bakker, A.B., \& Leiter, M. (2014). Burnout and job performance: The moderating role of selection, optimization, and compensation strategies. Journal of Occupational Health Psychology 19 (1), 96-107.

De Vaus, D., \& McAllister, I. (1991), Gender and Work Orientation: Values and Satisfaction in Western Europe. Work and Occupations, 18 (1), .72-93.

Diener, E. (2000). Subjective Well-Being: The Science of Happiness and a Proposal for a National Index. American Psychologist, 55 (1), 34-43.

*Dinler, A. (2010). Isparta ili otel işletmelerinde çalışanların iş doyumu ve tükenmişlik düzeyleri ile etkileyen etmenler (Yayımlanmamış yüksek lisans tezi). Süleyman Demirel Üniversitesi, Isparta.

*Dönmez, B. (2008). Seyahat acentasında çalışan işgörenlerin iş doyumu ve tükenmişlik düzeyi arasındaki ilişki (Yayımlanmamış yüksek lisans tezi). Mersin Üniversitesi, Mersin.

Duval, S. (2005). The trim and fill method. In H. R. Rothstein, A. J. Sutton, \& M. Bornstein (Eds.), Publication bias in meta-analysis: Prevention, assesment, and adjusments (pp. 11-33). Chichester, UK: John Wiley \& Sons.

Duval, S., \& Tweedie, R. (2000). Trim and fill: A simple funnel-plot-based method of testing and adjusting for publication bias in meta-analysis. Biometrics, 56, 455463.

*Erol, A., Sarıçiçek, A., \& Gülseren, Ş. (2007). Asistan hekimlerde tükenmişlik: İş doyumu ve depresyonla ilişkisi. Anadolu Psikiyatri Dergisi, 8, 241-247.

Fischer, H. J. (1983). A psychoanalytic view of burnout. In B. A. Farber (Ed.), Stress and burnout in the human service professions (pp. 40-45). Oxford: Pergamon.

*Gündoğdu, G. B. (2013). Sinıf ögretmenlerinin iş doyumu ve mesleki tükenmişlik düzeyleri üzerine bir çalışma: mersin ili örneği (Yayımlanmamış yüksek lisans 
tezi). Çă̆ Üniversitesi, Mersin.

*Güney, B. (2014). Sağlık meslek lisesi yöneticilerinin liderlik vasıfları ile meslek dersi ögretmenlerinin iş doyumu ve tükenmişlik düzeyleri arasındaki ilişki (Yayımlanmamış yüksek lisans tezi). İstanbul Sabahattin Zaim Üniversitesi, İstanbul.

Hedges, L.V., \& Olkin, I. (1985). Statistical method for meta-analysis. United Kingdom: Academic Press.

*Ilkım, T. Y. (2013). Türkiye'deki güreş hakemlerinin iş doyumu ve mesleki tükenmişlik düzeylerinin çeşitli faktörler açısından incelenmesi (Yayımlanmamış yüksek lisans tezi). İnönü Üniversitesi, Malatya.

Kahn, L.R. (1973). The work module: A tonic for lunchpail lassitude. Pyschology Today, 35-39.

*Kale, F. (2007). Beden ĕgitim öğretmenlerinin iş doyumu ve tükenmişlik düzeylerinin çeşitli değişkenler açısından incelenmesi (Yayımlanmamış yüksek lisans tezi). Niğde Üniversitesi, Niğde.

*Karahaliloğlu, N. (2013). Cerrahi kliniklerde çalışan hemşirelerde tükenmişlik ve iş doyumu düzeylerinin incelenmesi (Yayımlanmamış yüksek lisans tezi). Haliç Üniversitesi, İstanbul.

*Kargün, M. (2011). Futbol hakemlerinin iş tatmini ve mesleki tükenmişlik düzeylerinin çeşitli faktörler açısından incelenmesi (Yayımlanmamış yüksek lisans tezi). İnönü Üniversitesi, Malatya.

*Kaya, B. (2009). Ebelerin iş doyumu ve tükenmişlik durumlarını etkileyen faktörler (Yayımlanmamış yüksek lisans tezi). Adnan Menderes Üniversitesi, Aydın.

*Kaya, F. (2014). Duygusal emek ile tükenmişlik ve iş doyumu arasındaki ilişkinin incelenmesi: Aile ve Sosyal Politikalar Bakanlı̆̆l'na bağll huzurevlerinde çalışan yaşlı bakım personeline yönelik bir araştırma (Yayımlanmamış yüksek lisans tezi). Celal Bayar Üniversitesi, Manisa

Lipsey, M. W., \& Wilson, D. B. (2001). Practical meta analysis. London: SAGE Publications

Littel, H. J., Corcoran, J., \& Pillai, V. (2008). Systematic reviews and meta-analysis. New York: Oxford University Press.

Locke, E. (1976) The nature and causes of job satisfaction, In M. D. Dunnette (Ed.).Handbook of industrial and organizational psychology, Chicago: Rand McNally, 1297-1349.

Luthans, F. (1992). Organizational Behavior. 6 th Ed. USA: McGraw Hill

Maslach, C. (1976). Burned-out. Human Relations, 15, 16-22.

Maslach, C. (1982). Burnout: The cost of caring. englewood cliffs. NJ: Prentice-Hall.

Maslach, C., \& Jackson, S. E. (1981). The measurement of experienced burnout. Journal of Occupational Behavior, 2, 99-113.

Maslach, C., \& Jackson, S. E. (1982). Burnout in health professions: A social psychological analysis. In G. Sanders, \& J. Suls (Eds.), Social psychology of 
health and illness (pp. 227-251). Hillsdale, NJ: Erlbaum.

Maslach, C., \& Jackson, S. E. (1985). The role of sex and family variables in burnout. Sex Roles, 12(7/8), 837-851.

*Menteşe, M. (2007). İş doyumu, rol çatışması ve rol belirsizliği ile çalışanlarının tükenmişlik düzeyi arasındaki ilişkinin incelenmesi: Banka çalışanları üzerinde bir uygulama (Yayımlanmamış yüksek lisans tezi). Dumlupınar Üniversitesi, Kütahya.

*Oktar, M. N. (2015). Engelli bireylerle çalışanlarda algılanan örgütsel destek ve tükenmişlik düzeyinin iş tatmini üzerindeki etkisi: İstanbul ili beykoz ilçesi örneği (Yayımlanmamış yüksek lisans tezi). Yalova Üniversitesi, Yalova.

*Oral, L., \& Köse, S. (2011). Hekimlerin duygusal emek kullanımı ile iş doyumu ve tükenmişlik düzeyleri arasındaki ilişkiler üzerine bir araştırma. Süleyman Demirel Üniversitesi İktisadi ve İdari Bilimler Fakültesi Dergisi, 16 (2), 463-492.

*Örkün, Ü. (2011). Tekstil sektörü mavi yaka çalışanlarının yaşam doyumu ve tükenmişlik düzeylerinin iş doyumu tarafindan yordanması (Yayımlanmamış yüksek lisans tezi). Çukurova Üniversitesi, Adana.

*Özden, D., Karagözoğlu, Ş., \& Yıldırım, G. (2013). Intensive care nurses’ perception of futility: Job satisfaction and burnout dimensions. Nursing Ethics, 20(4), 436447.

*Özçelik, B. (2009). Belediyelerde çalışan işgörenlerin durumluluk kaygı, iş doyumu ve tükenmişlik düzeylerinin çeşitli değişkenler açısından incelenmesi (Yayımlanmamış yüksek lisans tezi). Maltepe Üniversitesi, İstanbul.

Pines, A., Aronson, E., \& Kafry, D. (1981). Burnout: From tedium to personal growth. New York: The Free Press.

Pines, A. M., \& Kafry, D. (1981). Tedium in the life and work of professional women as compared with men. Sex Roles, 7(10), 963-977.

Sarros, J. C. , \& Sarros, A. M. (1987). Predictors of Teacher Burnout. The Journal of Educational Administration, 24(2), 272-280.

*Sat, S. (2011). Örgütsel ve bireysel özellikler açısından iş doyumu ile tükenmişlik düzeyi arasındaki ilişki: Alanya'da banka çalışanları üzerinde bir inceleme (Yayımlanmamış yüksek lisans tezi). Çukurova Üniversitesi, Adana.

Scanlan, J. N., \& Still, M. (2013). Job satisfaction, burnout and turnover intention in occupational therapists working in mental health. Australian Occupational Therapy Journal, 60 , 310-318.

Schultz, D. P., \& Schultz, S. E. (2005). Psychology and work today. USA: Pearson.

*Sezgin, A. (2010). Üniversite hastanelerinde çalışan başmüdür ve müdürlerin iş doyumu ile tükenmişlik düzeylerinin incelenmesine yönelik bir araştırma (Yayımlanmamış yüksek lisans tezi). İstanbul Üniversitesi, İstanbul.

Shadish, W.R., Hedges, L.V., \& Pustejovsky, J.E. (2013). Analysis and meta-analysis of single-case designs with a standardized mean difference statistic: A primer and applications. Journal of School Psychology, 52, 123-147. 
Shraibman, F. K. (2008). An examination of the job satisfaction of the certified public accountants as it relates to their area of practice and their locus of control. (Unpublished Doctoral Thesis). New York University, USA.

Shields, J. (2007). Social servise work and job satisfaction: Revisiting Herzberg,Mauser \& Snyderman. (Unpuhlished Master Thesis). B.S Southwest Missouri State University, USA.

Siu, O.L.(2002), Experience Before and Throughout The Nursing Career, Predictors of Job Satisfaction and Absenteeism in Two Samples of Hong-Kong Nurses, Journal of Advanced Nursing, 40 (2) 218-229.

*Sumeli, F. (2011). Özel bir hastane çalışanlarının tükenmişlik ve iş doyumu düzeylerinin bazı değişkenler açısından incelenmesi (Yayımlanmamış yüksek lisans tezi). Marmara Üniversitesi, İstanbul.

*Sünter, A. T., Canbaz, S., Dabak, Ş., Öz, H., \& Pekşen, Y. (2006). Pratisyen hekimlerde tükenmişlik, işe bağlı gerginlik ve iş doyumu düzeyleri. Genel Tip Dergisi 16 (1), 9-14.

*Şeker, B. D., \& Zırhlıoğlu, G. (2009). Van emniyet müdürlüğü kadrosunda çalışan polislerin tükenmişlik, iş doyumu ve yaşam doyumları arasındaki ilişkilerin değerlendirilmesi. Polis Bilimleri Dergisi, 11 (4), 1-26.

*Tanrıverdi, L. (2008). Illköğretim müfettişlerinin iş tatmini ile tükenmişlik düzeylerinin incelenmesi: İstanbul ili örneği (Yayımlanmamış yüksek lisans tezi). Yeditepe Üniversitesi, İstanbul.

*Teltik, H. (2009). Okul öncesi ögretmenlerinin mesleki yeterlilik algılarının iş doyumu ve tükenmişlik düzeyleriyle ilişkisinin belirlenmesi (Yayımlanmamış yüksek lisans tezi). Maramara Üniversitesi, İstanbul.

Thalheimer, W., \& Cook, S. (2002). How to calculate effect size from published research: a simplified spreadsheet. Retrieved 01 November 2014 from http://www.bwgriffin.com/gsu/courses/edur9131/content/Effect_Sizes_pdf5.pdf.

*Toker, İ. (2013). Acil tıp uzmanlık öğrencilerinde iş doyumu ve tükenmişlik düzeylerini etkileyen faktörler (Yayımlanmamış yüksek lisans tezi). Mersin Üniversitesi, Mersin.

*Tunceli, D. H. (2012). Kabin ekiplerinde iş tatmini ve tükenmişlik duygusu: THY örneği (Yayımlanmamış yüksek lisans tezi). Atılım Üniversitesi, Ankara.

*Tunç, V. (2013). Tarih ögretmenlerinin iş doyum ve mesleki tükenmişlik düzeylerinin bazı değişkenler açısından incelenmesi: Van ili örneği (Yayımlanmamış yüksek lisans tezi). Yüzüncü Y1l Üniversitesi, Van.

*Umay, G. (2015). Psikolojik danışman ve rehberlik ögretmenlerinin iş doyumu ve tükenmişlik düzeylerinin ilişkisi (Yayımlanmamış yüksek lisans tezi). Yeditepe Üniversitesi, İstanbul.

*Uyar, S., \& Erdinç, S. B. (2013). Muhasebe personelinin iş doyumu ve tükenmişlik düzeyi. MÖDAV Muhasebe Bilim Dünyası Dergisi, 1, 213-232.

*Üstünbaş, G. (2011). Türkiye'de fizyoterapistlerde tükenmişlik, iş doyumu ve yaşam kalitesi düzeylerinin araştırılması (Yayımlanmamış yüksek lisans tezi). Abant 
İzzet Baysal Üniversitesi, Bolu.

Verner, J. P. (2008). A descriptive study of educator job satisfaction and valued communications. (Unpublished doctoral thesis). University Of West Georgia, USA.

Wilson, C. (2009). Relative influences of arizona high school principals' job satisfaction. (Unpublished Doctoral Thesis). The Universty of Arizona, USA.

Wray, R. D., Luft, R. G., \& Highland, P. J. (1996). Human relations. USA: SouthWestern Educational Publishing.

Wright, T. A., \& Bonett, D. G., (1997). The contribution of burnout to work performance, Journal of Organizational Behavior, 18, 491-49.

*Yılmaz, M. (2009). Yatılı ilköğretim ve ortaöğretim okullarında görev yapan öğretmen ve idarecilerin iş tatmin düzeyleri ile tükenmişlik düzeylerinin karşılaştırılması: Inebolu ilçesi örneği (Yayımlanmamış yüksek lisans tezi). Yeditepe Üniversitesi, İstanbul.

*Yılmaz, Z. Ü. (2014). Sağllk çalışanlarının tükenmişlik, depresyon ve iş doyumu düzeylerinin incelenmesi (Yayımlanmamış yüksek lisans tezi). Haliç Üniversitesi, İstanbul.

*Yurtsever, N. (2015). İzmir'de çalışan evde bakım hemşirelerinin iş doyumu ve tükenmişlik düzeylerinin incelenmesi (Yayımlanmamış yüksek lisans tezi). İzmir Katip Çelebi Üniversitesi, İzmir.

*Yüksel, C. (2013). Hemşirelerde uyku kalitesi iş doyumu ve tükenmişlik arasındaki ilişkinin incelenmesi (Yayımlanmamış yüksek lisans tezi). Eskişehir Osmangazi Üniversitesi, Eskişehir 


\section{Appendix 1}

Summary of study characteristics of emotional exhaustion in the analysis results

\section{Meta Analysis}

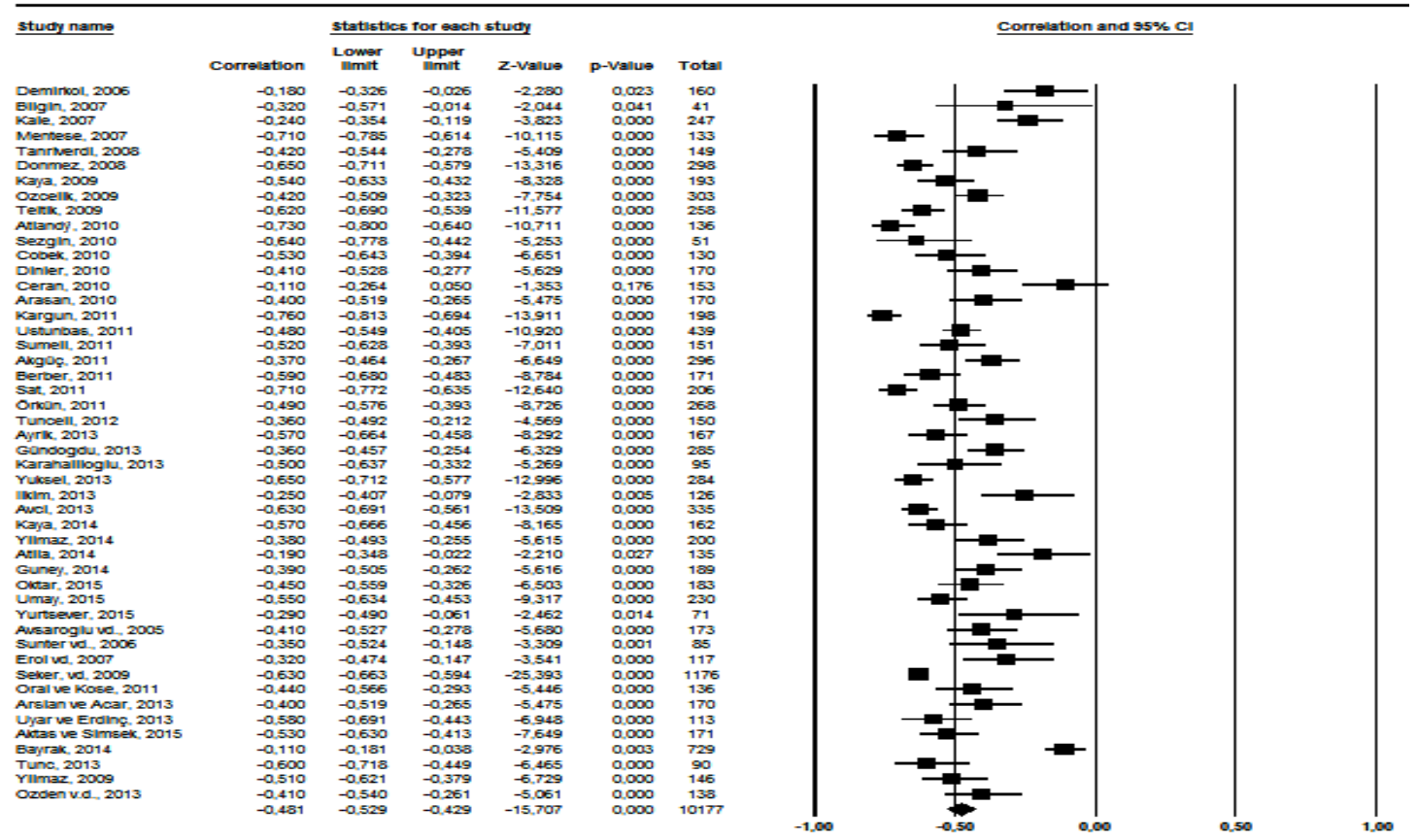

\section{Appendix 2}

Summary of study characteristics of depersonalization in the analysis results

Meta Analysis

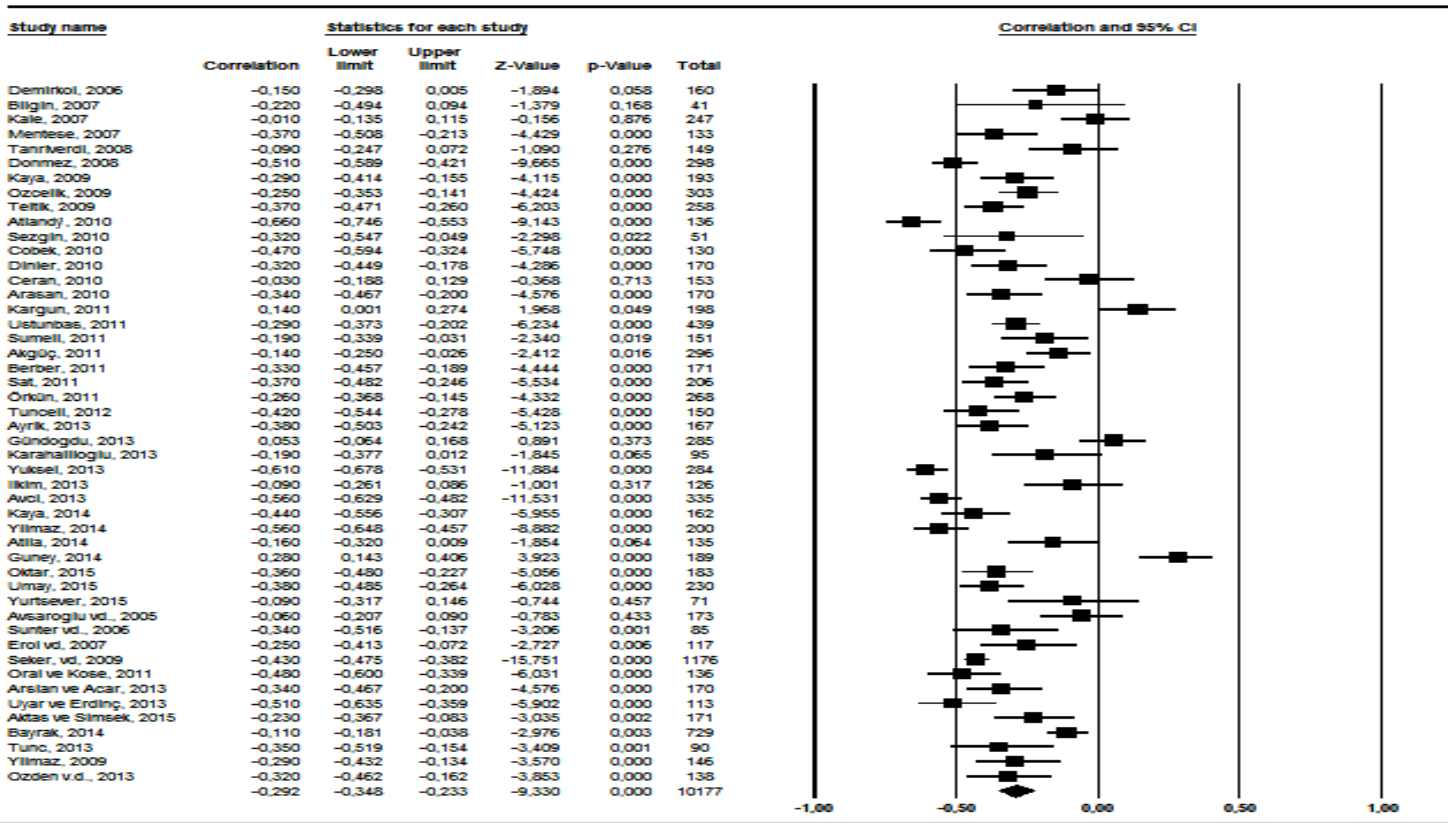




\section{Appendix 3}

Summary of study characteristics of reduced personal achievement in the analysis results

\section{Meta Analysis}

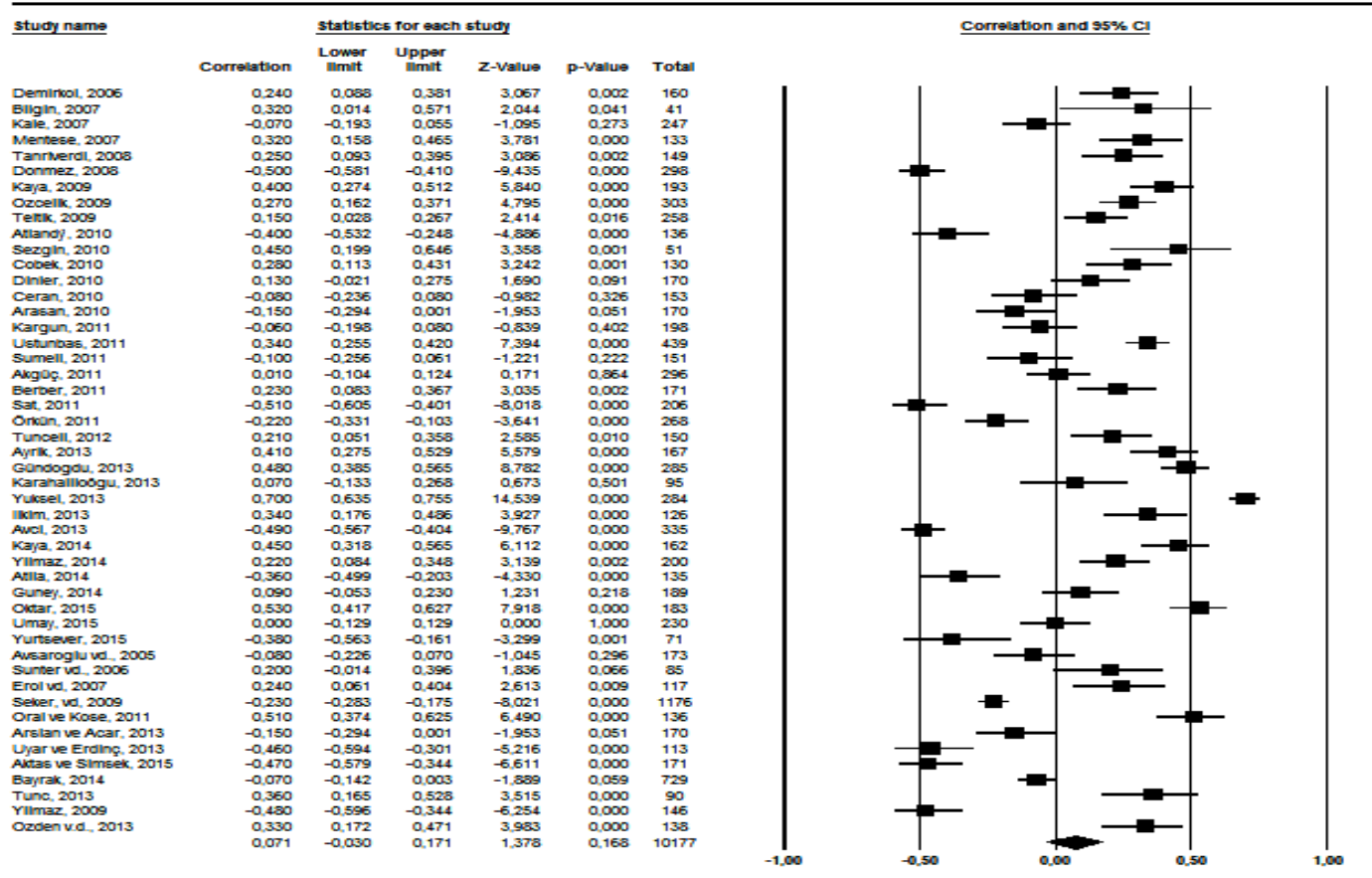

\section{Appendix 4}

Effect size funnel on publication bias

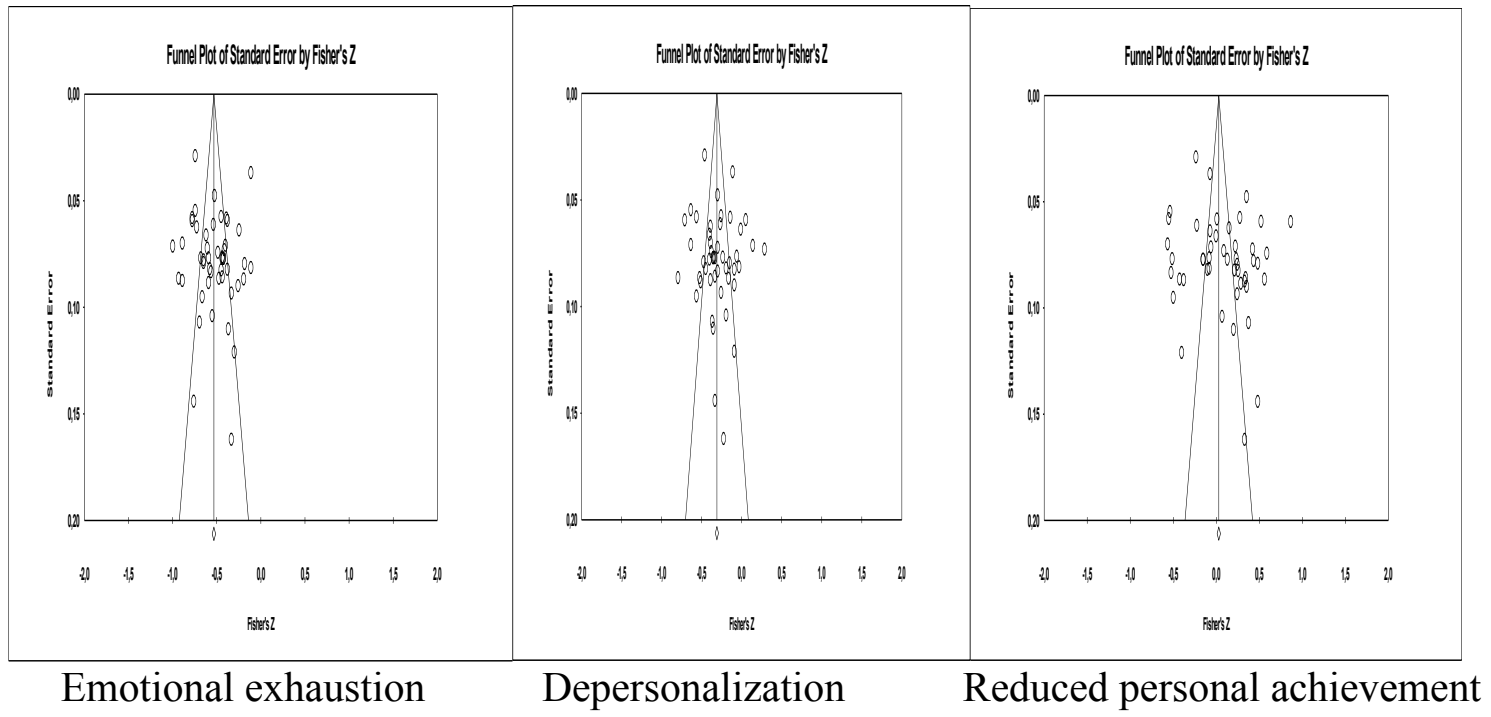

